\title{
Analysis of Consumer Purchase Patterns on Handphone Accessories Sales Using FP-Growth Algorithm
}

\author{
Devi Fitrianah ${ }^{1, *}$, Shifa Yasinta Zain ${ }^{2}$ \\ ${ }^{1,2}$ Universitas Mercu Buana, Meruya Selatan, Jakarta 11650, Indonesia \\ *Corresponding author.Email: ${ }^{1}$ devi.fitrianah@mercubuana.ac.id*, ${ }^{2}$ shifayasinta21@gmail.com
}

\begin{abstract}
This study aims to discover association patterns from customers' purchase, these patterns later on known as reference for the store to supply goods. Mapongs store is one of the online shops that is developing quite rapidly, however, Mapongs Store is still difficult to determine the supply of stock of goods to be sold, so this has an impact on decreasing sales figures. To solve this problem, the method used in this study is the Association rule using the FP Growth algorithm. Analysis of sales data obtained with the Association rules Method using the FP Growth algorithm, namely the greater the minimum support and minimum confidence used, the fewer itemset and rules will be formed. In this study, if the minimum support is $50 \%$ and the minimum confidence is $80 \%$, it will produce 211 rules. So, the rules in this study can be used as information for sellers to find out what products buyers often buy at this Mapongs Store. All Rules produced in this study have a Lift ratio value of more than 1.00 so they can be used as a reference in determining the relationship between product sales to optimize the results of sales analysis for sellers
\end{abstract}

Keywords: Data Mining, FP-Growth Algorithm, Association Rule

\section{INTRODUCTION}

Entrepreneurship is a business activity that involves the ability to see business opportunities that then organize, organize, take risks, and develop the business created to gain profit. One form of entrepreneurship in the current era is the Online Shop. According to Loekamto, Online Shop is a facility or store to offer goods and services through the internet so that online shop visitors can view items at the online shop [1]. The development of online shops in Indonesia is increasingly showing significant developments. Consumers are not only facilitated in shopping, but also services such as banks that introduce e-banking techniques.

Mapongs Store is an online shop that is engaged in selling mobile phone accessories. In its business, Mapongs Store is developing quite rapidly, but Mapongs Store is still difficult in determining the supply of goods to be sold so that it has an impact on the decline in sales figures. This problem requires sellers to find a pattern of consumer behavior from product sales transaction data. So that it can increase sales and minimize existing problems.

Based on these problems, it is necessary to have the right solution for the problems being faced in determining strategies to increase product sales and promotions, for example, product A with color B is more in demand by consumers, the seller can promote the product A with color B. Solution that used to make it happen is data mining. Data mining is the process of analysing data that is used to find a pattern from a data set [2]. Data mining can analyze large data into information such as patterns that have meaning for decision support. One of the data mining techniques that can be used is the association rule. Association rule is a method of analysis of the behaviour of consumers, specifically a particular group [3]. One algorithm that can be used to find association rules is to use the FP-Growth Algorithm.

With the FP-Growth algorithm, Frequent itemset will be searched without using a candidate generation. Also, many studies use FP-Growth algorithms and association rule methods, one of which is research on spare parts booking recommendation systems using the FP-Growth algorithm [4]. In his research produced a minimum value of support 0.15 and a minimum confidence of more than 0.6. The frequent itemset produced by the FP-Growth algorithm in his study produced 36 association rules so that they could be used as references and recommendations in purchasing spare parts. 
The data collected on the Mapongs Store sales data has useful information and can be used to make a decision and can obtain new knowledge about the pattern of product purchases. For example, if consumers have cell phones with type A, they will buy casing $\mathrm{B}$ and color $\mathrm{C}$. Therefore, the author tries to solve problems in the data using the FP-Growth Algorithm. Tests are carried out based on a brand of mobile phones, product name, quantity, and shipping status. Data processing is carried out on sales data of mobile accessories products in the 2015-2019 period with a sample of 40 months.

By knowing the pattern of consumer purchases of product sales like this, it is expected that sellers can find new and valuable information for Mapongs Store regarding which products are often purchased with certain cell phone brands so that they can assist in increasing product sales and promotions in Mapongs Store.

\section{LITERATURE REVIEW}

\subsection{E-Commerce}

Electronic Commerce or E-Commerce is a collection of technologies, applications, and businesses that connect companies or individuals as consumers to make online buying and selling transactions, exchanging goods, and exchanging information through the internet or television, www, or other computer networks [5].

According to Irmawati in her research revealed that there are still weaknesses and constraints in purchasing on E-Commerce including many consumers who are still difficult or not understand in searching for shopping sites or online shops, do not understand how to order products on the website and then have to fear whether the card number their credit was taken by hackers [6].

In addition to the existence of obstacles or weaknesses, E-Commerce also has advantages such as those expressed by Harisno and Pujadi in their research, namely [7] :

a. New revenue streams that are more promising and cannot be found in traditional transactions. Because in the use of this technology it is realtime and does not care about the distance, space and time.

b. By using E-Commerce, you can easily find people from various regions. Because ECommerce is not fixed in one area.

c. With the availability of E-Commerce technology facilities, costs, especially for business operations, are becoming increasingly cheaper, such as the procurement of transaction paper, record books, and file storage racks, and so on.

d. Real-time communication will increase the speed and effectiveness of employee performance in the company so that the production process will become shorter and will increase, both in quantity and quality and following the superior market share.

\subsection{Data Mining}

Data mining is a process of selection, exploration, and modeling of large amounts of data to find patterns or tendencies that are usually not aware of its existence. besides that data mining can also be interpreted as extracting new information taken from large chunks of data that help in decision making [8].

According to Firdaus in his research in 2017 examining the application of data mining in a computerassisted learning system, it began with data collection, followed by data transformation, and ended with data analysis. In data collection, it must be defined as a model of interaction between students and the system to establish data that must be recorded from a learning process. The student interaction model on the system can be composed of several layers to enable the acquisition of data at different levels of granularity [9].

\subsection{Consumer Purchase Patterns}

A pattern is a form or model or, more abstractly, a set of rules that can be used to create or to produce a part or part of something, especially if the thing that is caused has something of a kind for the archetype that can be shown or seen, which something is said to show off a pattern. Definition of Purchase is an event or action taken by two parties to exchange goods or services using a valid transaction tool and both have an agreement in the transaction. Consumers are every person using goods and or services available in society, whether for the benefit of themselves, their families, or others.

In his research, John Dawes said about the law of purchase, If smokers buy more than one brand of cigarettes in a period of like a year, what other brands do they tend to buy? In many other markets, a predictable pattern of cross-brand buying has been found where competing brands $\mathrm{A}, \mathrm{B}, \mathrm{C}, \mathrm{D}$, etc. tend to share customers in line with each other's penetration. This means that if $\mathrm{A}$ and $\mathrm{B}$ are larger brands than $\mathrm{C}$ and $\mathrm{D}$, then A will share more of its buyers with the other big B brands and fewer of its buyers with smaller C and D brands. This pattern is called the Legal Duplication of Purchase [10].

\subsection{FP-Growth Algorithm}

The Frequent Pattern Growth (FP-Growth) algorithm is a developer of a priori algorithms. FPGrowth is one algorithm that can be used to determine the set of data that often appears or is called frequent itemset in a data set [11]. The FP-Growth Frequent Pattern Algorithm has three main stages, namely [12]: 
a. Conditional Pattern Base Generation, at this stage the Conditional Pattern Base is a sub-database that contains a prefix path and suffix pattern. The generation of a conditional pattern base is obtained through FP-Tree that has been built before.

b. Conditional FP-Tree Generation, at this stage, support count of each item on each conditional pattern base is summed, then each item that has several support counts is greater or equal to the minimum support count that will be generated with a conditional FP-Tree.

c. Frequent Itemset Search, at this stage it will be seen, if the conditional FP-Tree is a single path (single path), then it gets a frequent pattern by doing a combination of items for each conditional FP-Tree. If it is not a single trajectory, the recursive generation of FP-Growth is carried out.

\subsection{Market Basket Analysis}

Market basket analysis is an analysis of consumer habits in shopping at supermarkets by finding the rules of association and correlation between various types of products that consumers enter their shopping baskets [13]. Market basketball analysis is often referred to as the function of the association rule. This function is most widely used to analyze data for the purposes of marketing strategies or decision-making processes in business [14].

\subsection{Association Rule}

Association rule is a data mining technique to find the rules of association between an item combination. Association rules or affinity analysis regarding 'what is together'. This can be a study of transactions in supermarkets, for example, people who buy product A also buy product B [15]. There are 2 stages in the Association Rule, namely [16]:

a. Looking for the most common combination of items (frequent itemset).

b. Generating Association Rule from frequent itemset that has been made before.

In the association rule there is a basic methodology which is divided into two stages, namely [17]:

a. Analysis of High-Frequency Patterns

At this stage, it will look for item combinations that meet the minimum requirements of the support value in the database.

The value of the support item is obtained by the formula as follows:

$$
\text { Support }(\mathrm{A})=\frac{\text { number of transactions contains } A}{\text { Total Transactions }}
$$

While the value of the support of the two items is obtained by the formula:

Support $(\mathrm{A}, \mathrm{B})=\frac{\text { number of transactions containing } A \text { and } B}{\text { Total Transactions }}$ b. Establishment of Association Rule

At this stage, we will look for association rules that meet the minimum requirements of confidence values. Value of confidence is obtained by the formula as follows:

$$
\begin{gathered}
\text { Confidence }=f P(\mathrm{~A} \mid \mathrm{B})= \\
\frac{\text { number of transactions containing } A \text { and } B}{\text { number of transactions contains } A}
\end{gathered}
$$

c. Analysis of Lift Ratio

Lift ratio is a value that shows the validity of the transaction process and provides information "is it true that product $\mathrm{A}$ is purchased together with product B". Lift ratio can measure how important rules have been formed based on the value of support and value of confidence. Lift ratio is obtained by the following formula:

$$
\text { Lift Ratio }=\frac{\text { Confidence }(A, B)}{\text { Banchmark Confidence }(A . B)}
$$

To get benchmark confidence values can be calculated using the following formula:

$$
\text { Banchmark Confidance }=\frac{N C}{N}
$$

Information:

NC : Number of transactions with items that have become consequent.

$\mathrm{N} \quad$ : Number of database transactions

\subsection{Previous Studies on Frequent Pattern Growth (FP-Growth)}

There are several studies related to association rules and FP-Growth algorithms. The similar issue taken this approach for enhancing the sales is done by Hartono and Fitrianah [18]. The study used the FP-Growth algorithm to find interesting patterns in transaction database so that it can be used as recommendation sales promotion and inventory products. In 2018, Wijaya and Fitrianah discussed the issue of potential fish-catching areas for fishermen using the association rule method and FPGrowth algorithm. The results obtained from the analysis are the greater the minimum support and minimum confidence used, the fewer items and rules are formed. at the minimum support and minimum confidence level with a minimum supply of $50 \%$ and minimum confidence of $80 \%$, we can be sure that when YellowFin tuna is obtained it will get Bigeye tuna too [19].

Prahatiwi in her research in 2017 discussed the frequent itemset search for transactions that occur in supermarkets using the FP-Growth algorithm. The experimental results obtained by the association rules that the frequent itemset is a combination of itemset beer wine spirits - frozen foods and snack foods. The 
resulting support value is 0.156 or $15.6 \%$, while the confidence value is $0.838(83.8 \%)$. This means that if customers buy beer wine spirits and frozen foods, those customers will also buy snack foods products [20].

\section{METHODOLOGY}

Figure 1 shows the first stage of the research, namely data collection until the final stage to obtain the results of the analysis from this study.

\subsection{Data Collection}

The dataset used in this study is sales transaction data in Mapongs Store within 40 months (October 2015 - February 2019). The total data used is 2924 sales transaction data. Examples of data sets used in this study will be explained in Table 1 .

\subsection{Pre-Processing Data}

Pre-Processing is the stage after data collection. Pre-Processing is the initial stage in data mining techniques to prepare data to make it easier to process [21]. At this stage, what is done is to select the appropriate attributes within the scope of the research. From all sales transaction data, only a few attributes are used. Table 2 shows the attributes that will be used after this Pre-Processing stage.

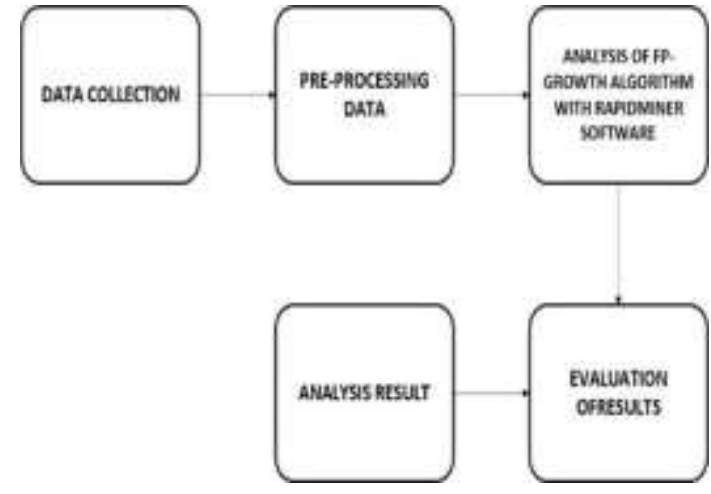

Figure 1. Block Diagram of Methodology

\subsection{Analysis of FP-Growth Algorithm with Rapidminer Software}

After all the data has been pre-processed, the data will be processed and tested using the RapidMiner software with the FP-Growth algorithm. The operator model used in Rapid Miner can be seen in Figure 2.

Table 1 Sales Transaction Dataset

\begin{tabular}{clll}
\hline Atributte & Description & Data Type & Data \\
\hline 1 & Date & Date & 21/10/2015 \\
\hline 2 & Seller & Polynomial & Mapongs Store \\
\hline 3 & Customer & Polynomial & Dadi Mulyady \\
\hline 4 & Handphone Brand & Polynomial & Iphone 5 \\
\hline 5 & Item Name & Polynomial & Tempered Glass \\
\hline 6 & Color & Polynomial & Transparan \\
\hline 7 & Qty & Int & 1 \\
\hline 8 & Price & Int & 32000 \\
\hline 9 & Shipping Status & Binominal & Accepted Returned
\end{tabular}

Table 2 Pre-Processing Data

\begin{tabular}{clll}
\hline Atributte & Description & Data Type & Data \\
\hline 1 & Handphone Brand & Polynomial & Iphone 5 \\
\hline 2 & Item Name & Polynomial & Tempered Glass \\
\hline 3 & Qty & Int & 1 \\
\hline 4 & Shipping Status & Binominal & Accepted Returned \\
\hline
\end{tabular}




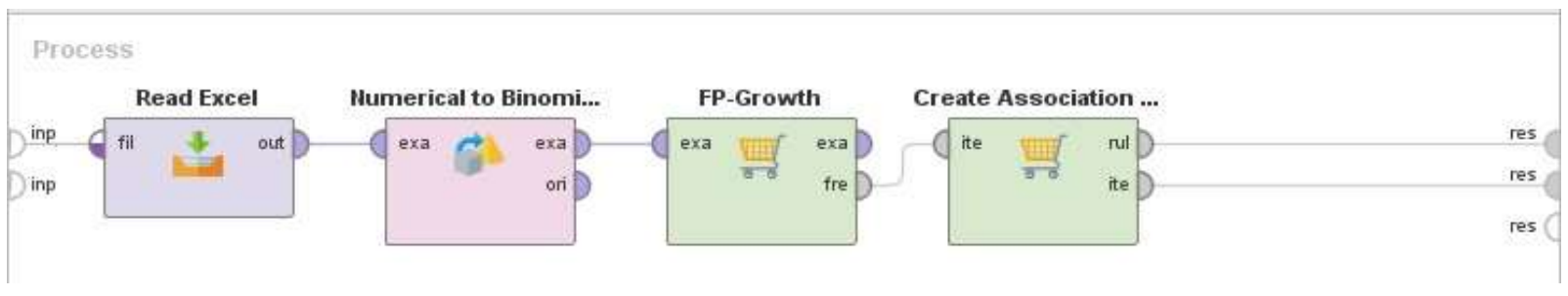

Figure 1. Operator of Rapidminer

The explanation of Figure 2 can be seen below:

a) Read Excel Operator: This operator is used to enter data that will be used for testing from Microsoft Excel to RapidMiner. After that, the user will be asked to define a spreadsheet that will be used as a data table.

b) Numerical To Binominal Operator: This operator is used to change the type of a numeric attribute to be binominal. The binominal attribute has only two values, namely "True" or "False".

c) FP-Growth Operator: This operator efficiently calculates all frequent itemsets that occur in ExampleSet. In simple words, a frequent itemset is a group of items that often appear simultaneously in transaction data. The discovery of frequent itemset is often referred to as the discovery of association rules.

d) Create Association Rule Operator: This operator generates several association rules from itemsets that are often given with predefined support values and confidence values. The Support value indicates how often the item appears in the database. Meanwhile, confidence shows how many times the statement "if / then" is found true. An example of an association rule is "If a customer buys eggs, $80 \%$ chance will buy milk".

\subsection{Evaluation of Results}

The research was conducted by testing data with different support and confidence values to find the best values and rules. The following are the results of testing data using the Rapidminer software. Analysis of the effect of Minimum Support on the Frequent Itemset.

Based on Table 3, it can be seen that the highest number of itemsets generated by the smallest minimum support in this data experiment is $10 \%$, while at least frequent itemsets are generated by minimum support of $20 \%, 30 \%, 40 \%$, and $50 \%$. This is because the minimum support value is the reference value of an itemset. Only items whose support value is equal to or greater than the minimum support value are used as a frequent itemset. Meanwhile, minimum confidence has no effect in generating frequent itemsets because there is no confidence calculation at this stage. So it can be concluded that the higher the minimum support used, the smaller the number of itemsets produced. In the tables below, examples of frequent itemset with minimum support of $10 \%$ to $50 \%$ will be displayed

Table 3 Frequent Itemset

\begin{tabular}{cccccc}
\hline Minsupp & $20 \%$ & $30 \%$ & $40 \%$ \\
\hline 1 & $10 \%$ & 239 & 211 & 178 \\
\hline 3 & 403 & 277 & 204 & 161 & 95 \\
\hline 4 & 197 & 240 & 111 & 26 & 22 \\
\hline
\end{tabular}


Table 4 Minimum Support 10\%

\begin{tabular}{|c|c|c|c|c|c|}
\hline Size & Support & Item 1 & Item 2 & Item 3 & Item 4 \\
\hline 1 & 1.000 & TRUE & & & \\
\hline 1 & 0.985 & accepted & & & \\
\hline 1 & 0.235 & Iphone 5 & & & \\
\hline$\ldots$ & $\ldots$ & $\ldots$ & $\ldots$ & $\ldots$ & $\ldots$ \\
\hline 4 & 0.004 & TRUE & Accepted & $\begin{array}{l}\text { Hard Case Cover Ultrathin } 0.30 \\
\text { Mm thick Black }\end{array}$ & Iphone 7 \\
\hline 4 & 0.003 & TRUE & Accepted & $\begin{array}{l}\text { Hard Case Cover Ultrathin } 0.30 \\
\text { Mm thick Black }\end{array}$ & Xiaomi Mi Note \\
\hline 4 & 0.004 & TRUE & accepted & $\begin{array}{l}\text { Hard Case Cover Ultrathin } 0.30 \\
\text { Mm thick Black }\end{array}$ & Iphone 7 Plus \\
\hline
\end{tabular}

Table 5 Minimum Support $20 \%$

\begin{tabular}{|c|c|c|c|c|c|}
\hline \multicolumn{2}{|c|}{ Size } & \multirow{2}{*}{$\frac{\text { Support }}{\text { TRUE }}$} & \multirow[t]{2}{*}{ Item 1} & \multirow[t]{2}{*}{ Item 2} & \multirow[t]{2}{*}{ Item 4} \\
\hline 1 & 1.000 & & & & \\
\hline 1 & 0.985 & accepted & & & \\
\hline 1 & 0.235 & Iphone 5 & & & \\
\hline$\ldots$ & $\ldots$ & $\ldots$ & $\ldots$ & $\ldots$ & $\ldots$ \\
\hline 4 & 0.022 & TRUE & Accepted & $\begin{array}{l}\text { Slim Case Cover Soft Case } \\
\text { Ultrathin } 0.30 \mathrm{Mm} \text { thick Black }\end{array}$ & Iphone 4s \\
\hline 4 & 0.017 & TRUE & Accepted & Xiaomi Mi5 & $\begin{array}{l}\text { Hard Case Cover } \\
\text { Ultrathin } 0.30 \mathrm{Mm} \\
\text { thick Black }\end{array}$ \\
\hline 4 & 0.015 & TRUE & Accepted & Iphone 6 Plus & $\begin{array}{l}\text { Case Cover Hard Case } \\
\text { Ultrathin } 0.30 \mathrm{Mm} \\
\text { thick Black }\end{array}$ \\
\hline
\end{tabular}

Table 6 Minimum Support 30\%

\begin{tabular}{|c|c|c|c|c|c|}
\hline Size & Support & Item 1 & Item 2 & Item 3 & Item 4 \\
\hline 1 & 1.000 & TRUE & & & \\
\hline 1 & 0.985 & Accepted & & & \\
\hline 1 & 0.235 & Iphone 5 & & & \\
\hline$\ldots$ & $\ldots$ & $\ldots$ & $\ldots$ & $\ldots$ & $\ldots$ \\
\hline \multirow[t]{2}{*}{4} & 0.022 & TRUE & Accepted & $\begin{array}{l}\text { Slim Case Cover Soft Case } \\
\text { Ultrathin } 0.30 \mathrm{Mm} \text { thick Black }\end{array}$ & Iphone $4 \mathrm{~s}$ \\
\hline & & & Accepted & & Hard Case Cover \\
\hline \multirow[t]{3}{*}{4} & 0.017 & TRUE & & Xiaomi Mi5 & Ultrathin $0.30 \mathrm{Mm}$ thick \\
\hline & & & & & Black \\
\hline & & & Accepted & & Case Cover Hard Case \\
\hline \multirow[t]{2}{*}{4} & 0.015 & TRUE & & Iphone 6 Plus & Ultrathin $0.30 \mathrm{Mm}$ thick \\
\hline & & & & & Black \\
\hline
\end{tabular}


Table 7 Minimum Support 40\%

\begin{tabular}{|c|c|c|c|c|c|}
\hline Size & Support & Item 1 & Item 2 & Item 3 & Item 4 \\
\hline 1 & 1.000 & TRUE & & & \\
\hline 1 & 0.985 & Accepted & & & \\
\hline 1 & 0.235 & Iphone 5 & & & \\
\hline$\ldots$ & $\ldots$ & $\ldots$ & $\ldots$ & $\ldots$ & $\ldots$ \\
\hline 4 & 0.022 & TRUE & Accepted & $\begin{array}{c}\text { Slim Case Cover Soft Case } \\
\text { Ultrathin } 0.30 \mathrm{Mm} \text { thick } \\
\text { Black }\end{array}$ & Iphone $4 \mathrm{~s}$ \\
\hline 4 & 0.017 & TRUE & Accepted & Xiaomi Mi5 & $\begin{array}{l}\text { Hard Case Cover Ultrathin } \\
0.30 \mathrm{Mm} \text { thick Black }\end{array}$ \\
\hline 4 & 0.015 & TRUE & Accepted & Iphone 6 Plus & $\begin{array}{c}\text { Case Cover Hard Case } \\
\text { Ultrathin } 0.30 \mathrm{Mm} \text { thick } \\
\text { Black } \\
\end{array}$ \\
\hline
\end{tabular}

Table 8 Minimum Support 50\%

\begin{tabular}{|c|c|c|c|c|c|}
\hline Size & Support & Item 1 & Item 2 & Item 3 & Item 4 \\
\hline 1 & 1.000 & TRUE & & & \\
\hline 1 & 0.985 & Accepted & & & \\
\hline 1 & 0.235 & Iphone 5 & & & \\
\hline$\ldots$ & $\ldots$ & $\ldots$ & $\ldots$ & $\ldots$ & $\ldots$ \\
\hline 4 & 0.017 & TRUE & Accepted & Iphone 6 & $\begin{array}{l}\text { Case Cover Slim Soft } \\
\text { Case Ultrathin } 0.30 \mathrm{Mm} \\
\text { thick Black }\end{array}$ \\
\hline 4 & 0.024 & TRUE & Accepted & $\begin{array}{l}\text { Slim Case Cover Soft Case } \\
\text { Ultrathin } 0.30 \mathrm{Mm} \text { thick Black }\end{array}$ & Iphone 4 \\
\hline
\end{tabular}

\subsection{Analysis of the Effect of Minimum support and Minimum Confidence on Rules}

Table 9 Number Of Rules

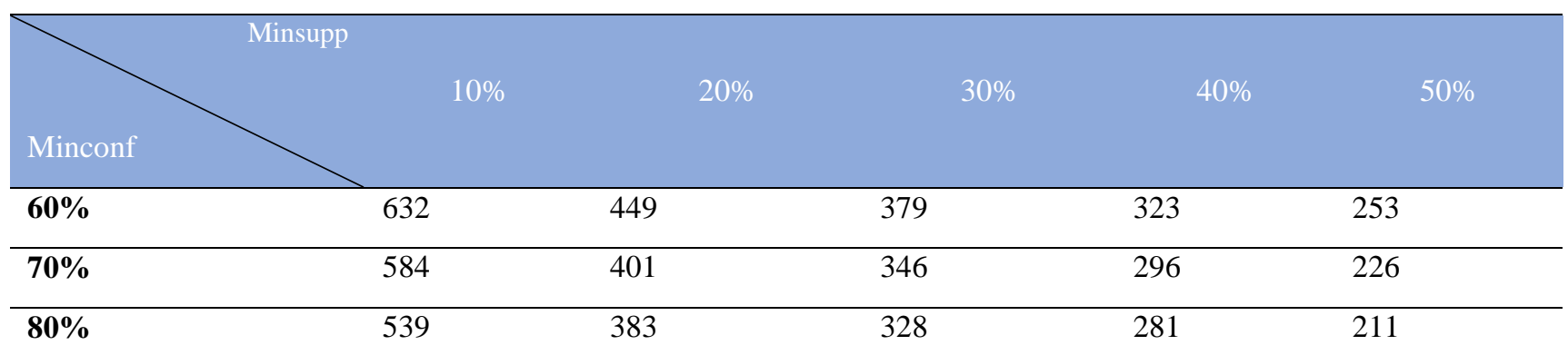

Based on Table 9, it can be seen that with 2924 data, the most number of association rules formed is generated by minimum support of $10 \%$ and minimum confidence of $60 \%$, which is 632 rules. With each additional minimum support and minimum confidence value that is tested, the resulting rules seem to decrease. This decrease is influenced by the number of frequent itemsets that have been generated by previous experiments. With minimum support of $50 \%$, it can be seen that fewer rules are formed, this is because the confidence value is higher than the frequent itemset. Therefore, it can be seen that minimum confidence affects the formation of rules. In this experiment, it can be concluded that the higher the minimum support value and the minimum confidence used, the fewer rules will be generated. 


\subsection{Lift Ratio Analysis Based on Rules Result}

Table 10. Lift Ratio

\begin{tabular}{|c|c|c|c|c|c|}
\hline No & Premises & Conclusion & Support & Confidence & Lift \\
\hline 1 & $\begin{array}{l}\text { Case Cover Hard Case Ultrathin } 0.30 \\
\text { Mm thick Black }\end{array}$ & $\begin{array}{l}\text { Accepted, Iphone } \\
6 \text { Plus }\end{array}$ & $10 \%$ & $80 \%$ & 24.976897689768975 \\
\hline 2 & $\begin{array}{l}\text { Case Cover Hard Case Ultrathin } 0.30 \\
\text { Mm thick Black }\end{array}$ & $\begin{array}{l}\text { true, accepted, } \\
\text { Iphone } 6 \text { Plus }\end{array}$ & $10 \%$ & $80 \%$ & 24.976897689768975 \\
\hline 3 & $\begin{array}{l}\text { Case Cover Hard Case Ultrathin } 0.30 \\
\text { Mm thick Black }\end{array}$ & $\begin{array}{l}\text { accepted, Iphone } \\
6 \text { Plus }\end{array}$ & $30 \%$ & $80 \%$ & 24.976897689768975 \\
\hline 4 & $\begin{array}{l}\text { Case Cover Hard Case Ultrathin } 0.30 \\
\text { Mm thick Black }\end{array}$ & $\begin{array}{l}\text { true, accepted, } \\
\text { Iphone } 6 \text { Plus }\end{array}$ & $30 \%$ & $80 \%$ & 24.976897689768975 \\
\hline 5 & $\begin{array}{l}\text { Case Cover Slim Soft Case Ultrathin } \\
0.30 \mathrm{Mm} \text { thick Gray }\end{array}$ & $\begin{array}{l}\text { accepted, Iphone } \\
5 \mathrm{C}\end{array}$ & $50 \%$ & $80 \%$ & 9.30025445292621 \\
\hline 6 & $\begin{array}{l}\text { Case Cover Slim Soft Case Ultrathin } \\
0.30 \mathrm{Mm} \text { thick Gray }\end{array}$ & $\begin{array}{l}\text { true, accepted, } \\
\text { Iphone } 5 \mathrm{C}\end{array}$ & $50 \%$ & $80 \%$ & 9.30025445292621 \\
\hline
\end{tabular}

Based on table 10, it can be seen that the lift ratio for all rules has a value greater than 1 (lift ratio> 1). This shows that all rules are strong and valid to be used as a reference to determine the correlation of sales of accessories products.

\section{RESULTS AND DISCUSSION}

Based on the evaluation of the results described in the previous point, it can be seen that the minimum level of support of $10 \%$ produces 4 frequent itemsets with a total of 998 items issued, while the minimum support of $50 \%$ still produces 4 frequent itemsets but the total items are reduced, namely 385 items.

Then for the effect of how many rules are generated by determining how much minimum support and minimum confidence to use, it can be seen by using minimum support of $10 \%$ and a minimum of $60 \%$ confidence resulting in as many as 632 rules. When using minimum support of $50 \%$ and a minimum of $80 \%$ confidence, it will produce the least rules, which are only 211 rules. For example, the minimum value of support and the highest minimum confidence, namely the minimum support of $50 \%$ and minimum confidence of $80 \%$, can be ascertained if the iPhone 6 brand cellphone will definitely buy accessories Case Cover Slim Soft Case Ultrathin Thickness 0.30 MM Black.

All rules generated with the minimum support in the previous point show a lift ratio of more than 1 , which means that these rules are valid to be used as references to find out the relationship between sales of accessories products at Mapongs Stor

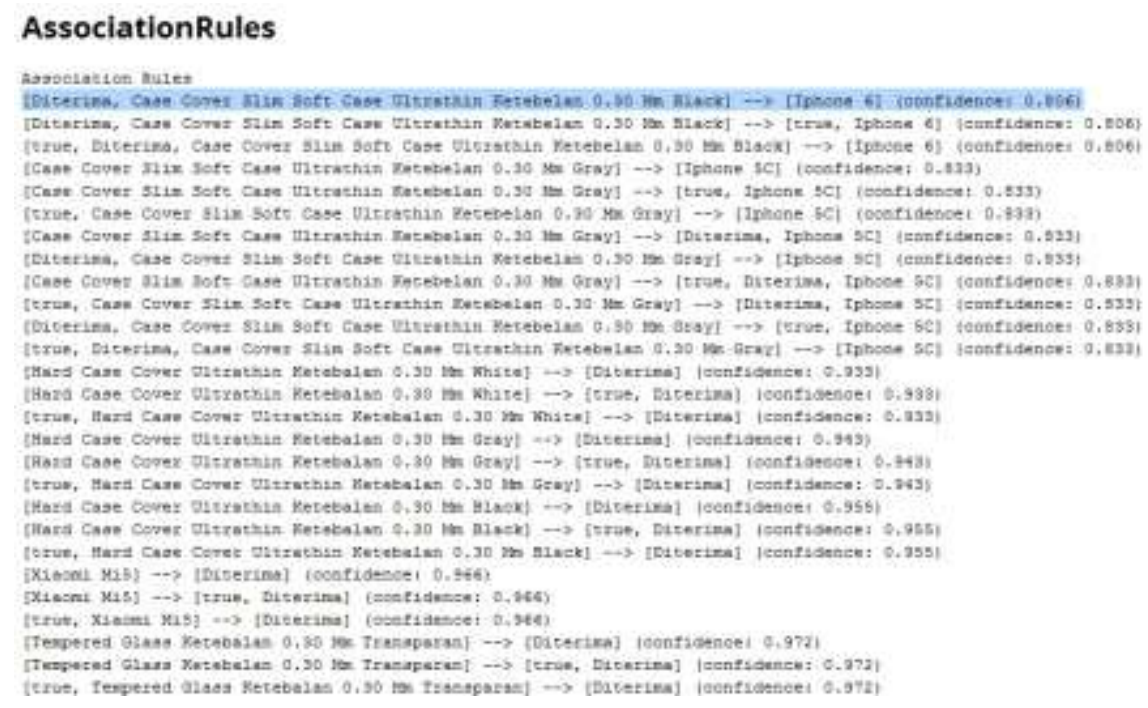

Figure 2. Association Rule 
In Figure 3, you can see the resulting rules with a minimum confidence of $80 \%$ and maximum confidence of $97 \%$. The highlighted line shows that the iPhone 6 brand cellphone will buy accessories. Case Cover Slim Soft Case Ultrathin Thickness 0.30 MM Black, with $80 \%$ confidence. Delivery status, which is Accepted and the quantity that is True, also affects the sales of accessories, which means that the delivery status and quantity of purchase have the potential to determine the rules for purchasing a cellphone brand with certain accessories and color products.

\section{CONCLUSION}

This study aims to help sellers at Mapongs Store to find out the relationship between product purchases, whether certain cellphone brands affect the purchase of accessories products. As well as to find out what accessories products are most often interested in.

From the results of the analysis, it can be concluded that the greater the minimum value of support and minimum confidence used, the less frequent items and rules are formed. All rules produced in this study are more than 1.00 so that these rules are valid as references to find out the relationship between sales of accessories products at Mapongs Store.

At the minimum value of support and the highest minimum confidence, namely the minimum support of $50 \%$ and minimum confidence of $80 \%$, it can be ascertained if the iPhone 6 brand cellphone will definitely buy accessories Case Cover Slim Soft Case Ultrathin Thickness 0.30 MM Black.

\section{FURTHER RESEARCH}

The limitations that exist in this study result in the need for further research to support and improve the research results obtained in this study. Further research is suggested to be carried out, namely by getting the best information and updated information so that it can increase the amount of data and compare the Apriori algorithm with the FP - Growth Algorithm. Another suggestion is to create a system that can display existing reports in analysis software so that it can make it easier for sellers to find information on products that they are most interested in.

\section{REFERENCES}

[1] A. Loekamto, "Implementasi Technology Acceptance Model (Tam) Dalam Online Shopping," Kaji. Ilm. Mhs. Manaj., pp. 1-5, 2012, [Online]. Available: http://journal.wima.ac.id/index.php/KAMMA/ar ticle/download/341/314.

[2] G. Gunadi and D. I. Sensuse, "Penerapan Metode Data Mining Market Basket Analysis
Terhadap Data Penjualan Produk Buku Dengan Menggunakan Algoritma Apriori Dan Frequent Pattern Growth ( Fp-Growth ):," Telematika, vol. 4, no. 1, pp. 118-132, 2012.

[3] V. N. Latifah, M. T. Furqon, and N. Santoso, "Implementasi Algoritme Modified-Apriori Untuk Menentukan Pola Penjualan Sebagai Strategi Penempatan Barang Dan Promo," vol. 2, no. 10, pp. 2829-2834, 2018.

[4] N. R. Ardani and N. Fitriana, "Sistem Rekomendasi Pemesanan Sparepart Dengan Algoritma Fp-Growth," Semin. Nas. Apl. Teknol. Inf. dan Multimed., pp. 6-7, 2016.

[5] A. Achmad, "Pengaruh Pengguna E-commerce terhadap Transaksi Online Menggunakan Konfirmasi faktor Analisis," Fakt. Exacta, vol. 11, no. 1, p. 7, 2018, doi: 10.30998/faktorexacta.v11i1.2306.

[6] D. Irmawati, "Pemanfaatan E-Commerce Dalam Dunia Bisnis," J. Ilm. Orasi Bisnis - ISSN 20851375, vol. Edisi Ke-V, no. November, pp. 95112,2011

[7] H. Harisno and T. Pujadi, "E-Business Dan ECommerce Sebagai Trend Taktik Baru Perusahaan," CommIT (Communication Inf. Technol. J., vol. 3, no. 2, p. 66, 2016, doi: 10.21512/commit.v3i2.516.

[8] S. Haryati, A. SudarsonHaryati, S., Sudarsono, A., \& Suryana, E. (2015). Implementasi Data Mining untuk Memprediksi Masa Studi Mahasiswa Menggunakan Algoritma C4.5. Jurnal Media Infotama, 11(2), 130-138.o, and E. Suryana, "Implementasi Data Mining untuk Memprediksi Masa Studi Mahasiswa Menggunakan Algoritma C4.5," J. Media Infotama, vol. 11, no. 2, pp. 130-138, 2015.

[9] D. Firdaus, "Penggunaan Data Mining dalam Kegiatan Sistem Pembelajaran Berbantuan Komputer," J. Format, vol. 6, no. 2, pp. 91-97, 2017.

[10] J. Dawes, "Cigarette brand loyalty and purchase patterns: An examination using US consumer panel data," J. Bus. Res., vol. 67, no. 9, pp. 1933-1943, 2014, doi: 10.1016/j.jbusres.2013.11.014.

[11] B. D. Meilani and W. Azmuri, "Penentuan Pola Yang Sering Muncul Untuk Penerima Kartu Jaminan Kesehatan Masyarakat (JAMKESMAS) Menggunakan Metode FPGrowth," Semin. Nas. "Inovasi dalam Desain dan Teknol., pp. 424-431, 2015.

[12] P. C. Purba and E. Siswanto, "Implementasi Algoritme FP-Growth Untuk Market Basket Analysis Dalam Menentukan Product Bundling," pp. 117-128, 2018, doi: 
10.1016/b978-012369512-3/50035-4.

[13] K. Tang, Y. L. Chen, and H. W. Hu, "Contextbased market basket analysis in a multiple-store environment," Decis. Support Syst., vol. 45, no. 1 , pp. 150-163, 2008, doi: 10.1016/j.dss.2007.12.016.

[14] Z. Wardah and D. Fitrianah, "Implementasi Data Mining Pada Penjualan Tiket Pesawat Menggunakan Algoritma Apriori (Studi Kasus: PT. Ceria Travel)," 2017.

[15] D. Listriani, A. H. Setyaningrum, and F. E. M. A, "Penerapan Metode Asosiasi Menggunakan Algoritma Apriori Pada Aplikasi Analisa Pola Belanja Konsumen ( Studi Kasus Toko Buku Gramedia Bintaro )," J. Tek. Inform., vol. 9, no. 2, pp. 120-127, 2016.

[16] D. Fitrianah and A. Hodijah, "Association Rule Antar Itemset Berdasarkan Periode Penjualan Dalam Satu Transaksi,” pp. 78-88, 2005.

[17] D. K. Pane, "Implementasi Data Mining Pada Penjualan Produk Elektronik Dengan Algoritma Apriori ( Studi Kasus: Kreditplus )," Pelita
Inform. Budi Darma, vol. valume: I, no. 3, pp. 25-29, 2013, doi: 2301-9425.

[18] H. H and D. Fitrianah, "A Data Mining Approach For Product Promotion and Inventory Solution using FP-Growth Algorithm," Int. J. Comput. Appl., vol. 177, no. 38, pp. 37-44, 2020, doi: 10.5120/ijca2020919889.

[19] D. Sukma and D. Fitrianah, "Data Mining Analysis with Association Rules Method to Determine the Result of Fish Catch using FPGrowth Algorithm," Int. J. Comput. Appl., vol. 181 , no. 15 , pp. $7-15,2018$, doi: 10.5120/ijca2018917748.

[20] L. I. Prahartiwi, "Pencarian Frequent Itemset pada Analisis Keranjang Belanja Menggunakan Algoritma FP-Growth," Inf. Syst. Educ. Prof., vol. 2, no. 1, pp. 1-10, 2017.

[21] A. Amalia, M. S. Lydia, S. D. Fadilla, and M. Huda, "Perbandingan Metode Klaster dan Preprocessing Untuk Dokumen Berbahasa Indonesia," J. Rekayasa Elektr., vol. 14, no. 1, pp. 35-42, 2018, doi: 10.17529/jre.v14i1.9027. 